\title{
Association between malnutrition in children living in favelas, maternal nutritional status, and environmental factors
}

\author{
Kátia B. R. Silveira, ${ }^{1}$ Jullyana F. R. Alves, $^{2}$ Haroldo S. Ferreira, $^{3}$ \\ Ana L. Sawaya, ${ }^{4}$ Telma M. M. T. Florêncio ${ }^{3}$
}

\begin{abstract}
Objective: To investigate the association of malnutrition in children living in substandard settlements (favelas) of Maceió, Brazil, with maternal nutritional status and environmental conditions.

Methods: Cross-sectional study involving a probability sample of 2,075 mothers (18 to 45 years) and their children ( 4 months to 6 years), living in the favelas of the city of Maceió. First, we conducted a cluster analysis with the purpose of choosing the settlements and the administrative region of the city of Maceio with the lowest human development index). After this analysis, the 7th Administrative Region was designated for the study, including its 23 substandard settlements. Socioeconomic, demographic, anthropometric, and maternal and child health data were collected by means of household survey. The statistical analysis included the odds ratio of a child to be malnourished, and the univariate regression was used to check which maternal variables were associated with this malnutrition.

Results: Chronic malnutrition ( -2 standard deviations/height for age) was found in $8.6 \%$ of children and was associated with mother's age and educational level, type of residence, number of rooms, flooring, water supply, and low birth weight $(<2,500 \mathrm{~g})$ in children aged $\leq 24$ months. We also found an association between child malnutrition and maternal height. Such association was not observed regarding body mass index.
\end{abstract}

Conclusions: The high prevalence of malnutrition observed in these settlements was related to social and environmental conditions and short maternal height, who had weight deficit or weight excess.

J Pediatr (Rio J). 2010;86(3):215-220: Stunting, obesity, poverty.

\section{Introduction}

Data from the Food and Agriculture Organization of the United Nations ${ }^{1}$ estimate that 963 million people are starving in the world, and $1 / 3$ of them are children usually affected by the most lethal type of malnutrition, proteinenergy malnutrition (PEM).

Although the prevalence of PEM has decreased a lot in Brazil, ${ }^{2}$ especially in the Northeast region, due to social differences, such health problem still remains an important public health issue, especially in some poverty areas located in the outskirts of large cities. ${ }^{3,4}$ However, in addition to the social context in which children live, child malnutrition is also determined by the biological factor, and the mother is an important interface between child and environment. ${ }^{5}$ Thus, poor maternal nutrition during pregnancy would result in low birth weight infants. Developmental deficits caused by intrauterine malnutrition and /or during early childhood

1. Mestre, Nutrição. Secretaria Estadual de Saúde de Alagoas, Brazil.

2. Mestranda, Nutrição, Faculdade de Nutrição, Universidade Federal de Alagoas (UFAL), Maceió, AL, Brazil.

3. Doutor. Professor, Faculdade de Nutrição, UFAL, Maceió, AL, Brazil.

4. Doutora. Professora, Departamento de Fisiologia, Disciplina de Fisiologia da Nutrição, Universidade Federal de São Paulo (UNIFESP), São Paulo, SP, Brazil.

5. Doutora. Professora, Faculdade de Nutrição, UFAL, Maceió, AL, Brazil.

This article is based on the Master's Degree thesis of the first author, which was presented at the School of Nutrition, Universidade Federal de Alagoas (UFAL), Maceió, AL, Brazil, in 2009.

Financial support: Fundo Nacional de Saúde/Ministério da Saúde.

No conflicts of interest declared concerning the publication of this article.

Suggested citation: Silveira KB, Alves JF, Ferreira HS, Sawaya AL, Florêncio TM. Association between malnutrition in children living in favelas, maternal nutritional status, and environmental factors. J Pediatr (Rio J). 2010;86(3):215-220.

Manuscript submitted Oct 16 2009, accepted for publication Jan 252010.

doi:10.2223/JPED.1991 
could lead to a reduction in the energy requirements with changes in the regulation of the endocrine system. ${ }^{6}$ These changes, which are so necessary to support life in the beginning, have harmful effect in the long term because they occur at the expense of growth reduction, making short height an important indicator of long-term nutritional disorder. ${ }^{5}$ Populations that have suffered chronic hunger have higher rates of short height, often correlated with a higher prevalence of obesity. ${ }^{7-9}$ In this sense, the study conducted by Florencio et al. ${ }^{7}$ in the favelas of Maceió, Brazil, found a prevalence of short height associated with obesity in $32 \%$ of the women and prevalence of child malnutrition in $21.6 \% .^{3}$

In Maceió, capital city of the state of Alagoas, $50 \%$ of the population lives under substandard conditions. ${ }^{10}$ In the 7th Administrative Region, one of the poorest in the municipality, there are 23 favelas and 81,000 inhabitants, of whom 21,000 are children. The objective of the present study was to investigate the association of child malnutrition with maternal nutritional status and social and environmental conditions in these favelas.

\section{Methods}

Cross-sectional population-based study conducted using a probability sample of mothers and children from the 23 substandard settlements (favelas) of the 7th Administrative Region of Maceió. This study is part of a larger project entitled "Training of Professionals Working for the Family Health Program and day care centers of the 7th Administrative Region of Maceió, " developed in partnership with the Ministry of Health/National Health Fund, aiming the diagnosis and treatment of all malnourished children from these settlements. The 7th Region was chosen because, in comparison to the others, it has the lowest human development index (HDI).

The sample size was estimated considering a prevalence of malnutrition of about $10 \%$ (height for age $<-2$ standard deviations) in children under 6 years old, with statistical power of $80 \%$ and $95 \%$ significance, resulting in a minimum sample of 90 children per favela. Next, we prepared the maps, and the settlements were visited in a clockwise direction from the corner chosen. We checked each house for the presence of at least one child under 6 years old. If a child under 6 was not found, the next house was visited until reaching the total of 2,100 households surveyed.

Children with genetic syndromes and who had short height, chronic diseases, such as acquired immunodeficiency syndrome (AIDS), neuropathies, diabetes, heart diseases, pregnant women, and non-biological mothers were excluded from the study. The final sample consisted of 2,075 mothers and children.

For the diagnosis and classification of malnutrition, we used the measure and indicators, according to age group, weight, and height, using the National Center for Health Statistics (NCHS) recommended by the World Health Organization (WHO) as a reference standard. ${ }^{11}$

Children older than 2 years were weighed using an electronic scale (capacity of $150 \mathrm{~kg}$ and accuracy of $0.1 \mathrm{~kg}$ ) previously calibrated. The subjects wore light clothing and were barefoot and their mothers or guardians were present. Height was measured using an anthropometer equipped with a 2-m inextensible measuring tape (accuracy of $0.1 \mathrm{~cm}$ ). Children under 2 years old were also weighed wearing light clothes, barefoot and without diapers while being held by their mothers. Children's final weight was determined by the difference between the mother's weight while holding the child and the mother's weight without holding the child, using the same scale. Length was measured using a portable wooden infantometer, with the child lying on a mattress suitable for measurement, his/her head positioned next to the fixed headpiece, keeping it parallel to the ruler, with knees pressed and feet together, with ankles in a $90^{\circ}$ angle, kept still using thefootpiece. After the collection of these measures, we calculated the height for age index, classifying the children's nutritional status according to the following cutoff points ( $z$ score): normal weight $=\geq-1$ to $\leq 1$; mild malnutrition $=<-1$ to $\geq-2 ;$ moderate malnutrition $=<-2$ to $\geq-3$; severe malnutrition $=<-3$; overweight $=>1$ to $\leq 2$; and obesity $=>2$.

Data regarding age, body weight, and height were collect for the anthropometric measurements of mothers. Body mass was obtained by means of portable electronic scale Marte PP180TM (São Paulo, SP, Brazil), with a capacity of $180 \mathrm{~kg}$ and sensitivity of $100 \mathrm{~g}$. For height measurement, all mothers were measured while standing up on a stadiometer equipped with a measuring tape with sensitivity of $0.1 \mathrm{~cm}$. All anthropometric measurements were obtained according to the recommendations of Frisancho. ${ }^{12}$ Short height was adopted as a marker of chronic malnutrition using a cutoff point lower than $155.0 \mathrm{~cm}$, which corresponds to the 5 th percentile of height for age, considering age $\geq 20$ years. ${ }^{13}$ Nutritional status was defined using body mass index $\left(\right.$ BMI $=$ weight $/$ height $\left.^{2}\right)$. We used the classification recommended by the WHO. ${ }^{14}$

The identification and social/environmental variables were collected using previously tested standardized forms. The dependent variable analyzed was child malnutrition, represented by a $z$ score of -2 for the height for age index.

The nominal and quantitative variables analyzed were divided into blocks, the first ones being properly categorized (codes: 0 = respondents with less favorable and/or lower/ equal condition in relation to the cutoff point established in advance, and 1 = respondents with more favorable and/or equal/higher condition in relation to the cutoff point also defined in advance) according to the hierarchical scheme shown below: 


\section{Socioeconomic characteristics:}

- Mother's educational level $0=$ mothers with 4 years of schooling or less, $1=$ mothers with more than 4 years of schooling.

- Family income: $\leq \mathrm{R} \$ 465.00=0$ and $>\mathrm{R} \$ 465.00=$ 1.

- Occupation: Unemployed $=0$ and employed $=1$.

Environmental characteristics:

- Housing: other $=0$ and house owner $=1$.

- Type of residence: other $=0$ and masonry house $=1$.

- Flooring: dirt floor $=0$ and masonry floor $=1$.

- Water supply: other $=0$ and public system $=1$.

- Waste disposal: other $=0$ and public system $=1$.

- Number of rooms in the house: $<4=0$ and $\geq 4=1$.

Maternal characteristics:

- Age: $\leq 30$ years $=0$ and $>30$ years $=1$.

- Height: $<1.55 \mathrm{~m}=0$ and $\geq 1.55 \mathrm{~m}=1$.

- $\quad$ BMI: $\leq 25 \mathrm{~kg} / \mathrm{m}^{2}=0$ and $>25 \mathrm{~kg} / \mathrm{m}^{2}=1$.

Child's characteristics and general status:

- Age: $\leq 24$ months $=0$ and $>24$ months $=1$.

- Birth weight: $<2,500 \mathrm{~g}=0$ and $\geq 2,500 \mathrm{~g}=1$.

\section{Statistical analysis}

We performed bivariate analyses using the chi-square test for the dichotomous variable height deficit in order to interpret the results. Using the variable outcome, we estimated odds ratio values adjusted for birth weight, their respective $95 \%$ confidence intervals (95\%CI) and experimental probability values.

Data collection was carried out after the mothers signed the written consent form. This study was approved by the Research Ethics Committee of Universidade Federal de Alagoas (UFAL), Maceió, state of Alagoas, Brazil, according to the guidelines of the National Research Ethics Committee (CONEP).

\section{Results}

Figures 1 and 2 show the nutritional status of children and mothers. We found that, of all the children, $8.6 \%$ had moderate and severe malnutrition, while overweight/obesity was present in $11.3 \%$. With regard to the mothers, $38.8 \%$ were short and $45.6 \%$ were overweight.

Table 1 shows the odds ratio for a mother to have a malnourished child. After analyzing the socioeconomic conditions, we found that almost all variables were significantly associated with malnutrition, especially maternal educational level, which showed that mothers with $\leq 4$ years of schooling were at approximately three times higher risk (2.6) of having a malnourished child than mothers with higher education. Additionally, the variables flooring, water supply, and number of rooms per household were essential for the diagnosis of malnutrition, and the most significant variable was type of residence $(p=0.01)$, ie, a house made of wood, canvas, paper, among others. Regarding the child's characteristics, we found that children aged $\leq 24$ months who had low birth weight $(<2,500 \mathrm{~g})$ were more susceptible to impairment of their nutritional status.

As for maternal anthropometric variables, they also were statistically related to child malnutrition. Maternal age was strongly associated with child malnutrition ( $p=0.006)$, followed by height. However, this correlation was not observed for BMI.

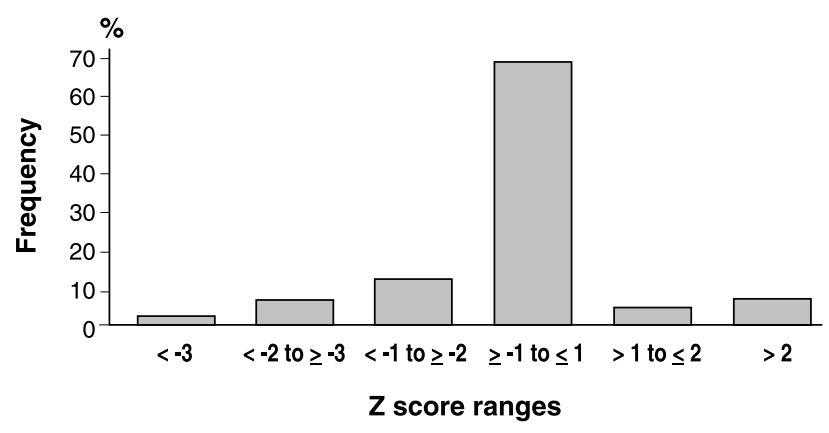

Figure 1 - Anthropometric classification of children under 6 years old living in the 7th Administrative Region according to $z$ score ranges of the height for age index - Maceió, Brazil, 2008

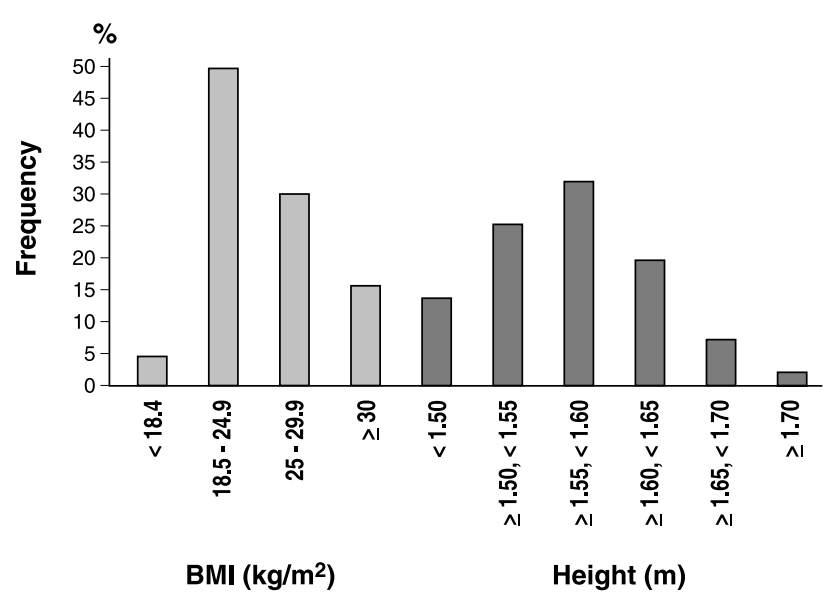

$\mathrm{BMI}=$ body mass index.

Figure 2 - BMI and height of mothers living in the 7th Administrative Region of Maceió, Brazil, 2008 
Table 1 - Child malnutrition according to socioeconomic and anthropometric variables of mothers living in the 7th Administrative Region of Maceió, Brazil, 2008

\begin{tabular}{|c|c|c|c|}
\hline Variable & n (\%) & Adjusted OR & $\mathbf{p}$ \\
\hline Mother's educational level (years) & & & 0.001 \\
\hline$\leq 4=0$ & $1,758(7.27)$ & 2.60 & \\
\hline$>4=1$ & $317(1.34)$ & 0.94 & \\
\hline \multicolumn{4}{|l|}{ Socioeconomic characteristics } \\
\hline Family income (reais) & & & 0.01 \\
\hline$\leq 465.00=0$ & $1,457(6.01)$ & 1.25 & \\
\hline$>465.00=1$ & $618(2.60)$ & 0.91 & \\
\hline Occupation & & & 0.03 \\
\hline Unemployed $=0$ & $1,761(7.27)$ & 2.03 & \\
\hline Employed $=1$ & $314(1.34)$ & 0.74 & \\
\hline \multicolumn{4}{|c|}{ Environmental characteristics: housing and family } \\
\hline Housing & & & 0.26 \\
\hline Other $=0$ & $745(3.13)$ & 0.84 & \\
\hline Home owner $=1$ & $1,330(5.48)$ & 0.82 & \\
\hline Type of residence & & & 0.01 \\
\hline Other $=0$ & $99(0.43)$ & 2.18 & \\
\hline Masonry house $=1$ & $1,976(8.18)$ & 1.00 & \\
\hline Flooring & & & 0.03 \\
\hline Dirt floor $=0$ & $1,400(5.83)$ & 1.25 & \\
\hline Masonry floor = 1 & $675(2.79)$ & 0.97 & \\
\hline Water supply & & & 0.03 \\
\hline Other $=0$ & $1,516(6.30)$ & 1.26 & \\
\hline Public system $=1$ & $559(2.31)$ & 0.97 & \\
\hline Waste disposal & & & 0.04 \\
\hline Other $=0$ & $1,861(7.70)$ & 1.99 & \\
\hline Public system $=1$ & $214(0.91)$ & 0.59 & \\
\hline Number of rooms in the house & & & 0.02 \\
\hline$<4=0$ & $353(1.49)$ & 1.82 & \\
\hline$\geq 4=1$ & $1,722(7.12)$ & 0.80 & \\
\hline \multicolumn{4}{|l|}{ Maternal characteristics } \\
\hline Age & & & 0.006 \\
\hline$\leq 30$ years $=0$ & $1,482(6.11)$ & 0.96 & \\
\hline$>30$ years $=1$ & $593(2.50)$ & 1.50 & \\
\hline Height & & & 0.001 \\
\hline$<1.55 \mathrm{~m}=0$ & $805(3.38)$ & 2.37 & \\
\hline$\geq 1.55 \mathrm{~m}=1$ & $1,270(5.24)$ & 0.32 & \\
\hline BMI & & & 0.06 \\
\hline$\leq 25 \mathrm{~kg} / \mathrm{m}^{2}=0$ & $1,145(4.71)$ & 0.85 & \\
\hline$>25 \mathrm{~kg} / \mathrm{m}^{2}=1$ & $930(3.90)$ & 1.11 & \\
\hline \multicolumn{4}{|c|}{ Child's characteristics and general status } \\
\hline Age & & & 0.02 \\
\hline$\leq 24$ months $=0$ & $685(5.73)$ & 1.22 & \\
\hline$>24$ months $=1$ & $1,390(2.88)$ & 0.98 & \\
\hline Birth weight & & & 0.01 \\
\hline$<2,500 \mathrm{~g}=0$ & $184(0.78)$ & 1.25 & \\
\hline$\geq 2,500 \mathrm{~g}=1$ & $1,891(7.84)$ & 0.87 & \\
\hline
\end{tabular}

$0=$ respondents with less favorable and/or lower/equal condition in relation to the cutoff point established in advance; $1=$ respondents with more favorable and/or equal/higher condition in relation to the cutoff point also defined in advance; BMI = body mass index; OR = odds ratio.

To better understand the influence of maternal height (an indicator of malnutrition in early life) and BMI on children's nutritional deficit, we tested the association between these variables (Table 2 ). When analyzing the mothers shorter than $1.55 \mathrm{~m}$, we found that short maternal height represented a double risk for malnutrition in their children. In relation to height and BMI, it appears that the excess and/or low weight alone were not significantly associated with child malnutrition. However, in the presence of short height, this association was highly significant ( $p<0,001$ ) with OR values equal to 2.61 and 2.42, respectively. 
Table 2 - Child malnutrition according to maternal height and BMI - 7th Administrative Region of Maceió, Brazil, 2008

\begin{tabular}{|c|c|c|c|c|}
\hline Maternal characteristics & Total children & Malnourished children (\%) & Adjusted OR & $\mathbf{p}$ \\
\hline \multicolumn{5}{|l|}{ Height } \\
\hline$<1.55 \mathrm{~m}=0$ & 805 & 6.83 & 2.27 & 0.01 \\
\hline$\geq 1.55 \mathrm{~m}=1$ & 1270 & 1.78 & 0.32 & \\
\hline \multicolumn{5}{|l|}{ BMI/height } \\
\hline$>25 \mathrm{~kg} / \mathrm{m}^{2}=1 ;<1.55 \mathrm{~m}=0$ & 83 & 2.70 & 2.41 & 0.01 \\
\hline$>25 \mathrm{~kg} / \mathrm{m}^{2}=1 ;<1.55 \mathrm{~m}=1$ & 847 & 1.13 & & \\
\hline$\leq 25 \mathrm{~kg} / \mathrm{m}^{2}=0 ;<1.55 \mathrm{~m}=0$ & 722 & 4.15 & 2.62 & 0.01 \\
\hline$\leq 25 \mathrm{~kg} / \mathrm{m}^{2}=0 ; \geq 1.55 \mathrm{~m}=1$ & 423 & 0.64 & & \\
\hline
\end{tabular}

$0=$ respondents with less favorable and/or lower/equal condition in relation to the cutoff point established in advance; $1=$ respondents with more favorable and/or equal/higher condition in relation to the cutoff point also defined in advance; BMI = body mass index; OR = odds ratio adjusted for "child's birth weight."

\section{Discussion}

Despite the use of the $\mathrm{NCHS}^{11}$ guidelines to determine the nutritional status of children up to 6 years instead of the WHO curves, ${ }^{15}$ because, at the time of the study, they only included children up to 5 years old, the prevalence of malnutrition found (8.6\%) among the children assessed was similar to that obtained in Nutritional Call (9.5\%) with a sample of 2,164 children living in the semi-arid region of Alagoas. ${ }^{16}$ This demonstrates that even those children living in the urban area of a large city are affected by a high prevalence of chronic malnutrition. In addition, there is the fact that these families lived in houses made of mud, wood, canvas and/or plastic, with no flooring, making it difficult to sanitize the environment and promoted the occurrence and development of pathogenic microorganisms, exacerbating the infection and the prevalence of malnutrition in children. These data are similar to those demonstrated by Romani \& Lira. ${ }^{17}$

In the present study, maternal educational level had the strongest correlation with malnutrition when compared to the socioeconomic variables. That is, the less educated the mother was the less attentive to the importance of personal hygiene habits and environment sanitization and the less able to provide adequate nutrition for the child's growth and development. These assertions were also confirmed by Florencio et al., ${ }^{3}$ Gage $^{18}$ and France et al. ${ }^{19}$ while investigating the relationship between environmental conditions and malnutrition in Kenya and in Brazil.

At present, approximately $70.2 \%$ of the sample had family income below one minimum salary ( $R \$ 465.00$ ), a condition which, combined with low maternal educational level, may decisively contribute to the lack of food or an inadequate choice of food, determining the nutritional problems observed in these children. Although malnutrition still stands out in a relevant manner, we observed that $11.3 \%$ of the children were overweight. Similar results were reported by Grillo et al. ${ }^{20}$ and Silva \& Mota ${ }^{21}$ while studying the favelas of São Paulo, state of São Paulo, Brazil, suggesting that the overweight found in these children $(12.6 \%)$ was possibly resulting from a chronic malnutrition as a consequence of maternal malnutrition and inadequate child nutrition early in life. According to Sawaya \& Roberts, ${ }^{6}$ a diet low in protein and minerals would result in a reduction in bone growth and lean body mass gains with reduced energy requirements to predispose the body to store body fat while consuming diets richer in fat and carbohydrates. We believe that these changes may be occurring in the children included in the present study.

If this inadequate food intake remains in adolescence and adulthood, it may lead to overweight, as observed in the high prevalence of overweight/obesity $(45.6 \%)$ in the women of this study, corroborating the percentage found by Barbosa et al. ${ }^{10}$ in same population.

On the other hand, this food intake, instead of being rich in energy, is poor in energy, especially those consumed by women at gestational age, it will favor the generation of a child with low birth weight. ${ }^{22}$ The children who were born with low birth weight included in the present study had, at 2 years old, greater susceptibility to the impairment of the nutritional status. According Ong, ${ }^{23}$ low birth weight associated with late introduction of complementary foods and a higher incidence of diarrhea, favored by the unhealthfulness of the environment, may determine the high prevalence of malnutrition observed in disadvantaged populations, such as those in our study. Within this context, height deficits observed inside the uterus and/or in the early childhood could determine the short height of adults. 9,24,25

In the present study, most mothers were short, which is also found in other studies with populations that were subjected to chronic hunger, determining the cycle of childhood malnutrition, short height, obesity, and comorbidities in adulthood. ${ }^{26-28}$ 
At present, we also demonstrated that statistically, regardless of the nutritional status of mothers, shorter height was directly associated with child malnutrition. Therefore, it is evident that both the genetic information and the socioeconomic and environmental conditions offered by the parents are transmitted and have an impact on the nutritional status of their children. ${ }^{29,30}$ That is, the absence or presence of nutritional deficits observed in children may be determined by a positive intrafamilial correlation.

Short height was also associated with child malnutrition in both the mothers with poor weight gain as those who are overweight, suggesting that short maternal height is independent of the current nutritional status as a risk factor for children's stunting. Thus, it is evident that short maternal height is an important predictor of malnutrition in children, being significantly associated with poverty and adverse environmental conditions.

\section{References}

1. FAO (Organización de las Naciones Unidas para la Agricultura y la Alimentación). Mapa de la desnutrición: un proceso en curso. Santiago: La Organización; 2009.

2. Ministério da Saúde [website], http://189.28.128.100/portal/ aplicacoes/noticias/noticias_detalhe.cfm?co_seq_noticia $=50298$. Access: 22/09/2008.

3. Florêncio TM, Ferreira HS, de França AP, Cavalcante JC, Sawaya AL. Obesity and undernutrition in a very-low-income population in the city of Maceió, northeastern Brazil. Br J Nutr. 2001;86:277-84.

4. Sawaya AL. Desnutrição: conseqüências em longo prazo e efeitos da recuperação nutricional. Estud Av. 2006;20:147-158.

5. Victora CG, Adair L, Fall C, Hallal PC, Martorell R, Richter L, et al. Maternal and child undernutrition: consequences for adult health and human capital. Lancet. 2008;371:340-57.

6. Sawaya AL, Roberts S. Stunting and future risk of obesity: principal physiological mechanisms. Cad Saude Publica. 2003;19 Suppl 1: S21-8.

7. Florêncio TT, Ferreira HS, Cavalcante JC, Luciano SM, Sawaya AL. Food consumed does not account for the higher prevalence of obesity among stunted adults in a very-low-income population in the Northeast of Brazil (Maceió, Alagoas). Eur J Cin Nutr. 2003;57:1437-46.

8. Barker DJ. Maternal nutrition, fetal nutrition and disease in later life. Nutrition. 1997;13:807-13.

9. Popkin BM, Richards MK, Montiero CA. Stunting is associated with overweight in children of four nations that are undergoing the nutrition transition. J Nutr. 1996;126: 3009-16.

10. Barbosa JM, Cabral PC, de Lira PI, Florêncio TM. Fatores socieconômicos associados ao excesso de peso em população de baixa renda no Nordeste brasileiro. Arch Latinoam Nutr, 2009;59:22-9.

11. World Health Organization. WHO child growth Standards: length/ height-for-age, weight-for-age, weight-for-length, weight-forheight and body mass index-for-age: methods and development. Geneva: WHO; 2006

12. Frisancho AR. Anthropometric standards for the assessment of growth and nutritional status. Ann Arbor: University of Michigan Press; 1990.
13. National Center for Health Statistic. Growth Curves 2000. http:// www.cdc.gov/growthchards. Access: 13/08/2005.

14. World Health Organization. Obesity: preventing and managing the global epidemic : report of a WHO consultation on obesity. Geneva: WHO; 1998.

15. World Health Organization. Who child growth standards: methods and development. Geneva: WHO; 2006.

16. UNICEF (Fundo das Nações Unidas para a Infância). Situação da Infância Brasileira. Brasil, 2006. http://www.unicef.org/brazil/ $\mathrm{pt} /$.

17. Romani SA, Lira PI. Fatores determinantes do crescimento infantil. Rev Bras Saúde Matern Infant. 2004;4:15-23.

18. Gage AJ. Familial and socioeconomic influences on children's well-being: an examination of preschool children in Kenya. Soc Sci Med. 1997:45:1811-28.

19. França E, Moreira de Souza J, Crosland Guimarães MD, Goulart EM, Colosimo E, de Figueiredo Antunes CM. Associação entre fatores sócio-econômicos e mortalidade infantil por diarréia, pneumonia e desnutrição em região metropolitana do Sudeste do Brasil: um estudo de caso-controle. Cad Saude Publica. 2001; 17:1437-47.

20. Grillo LP, Carvalho LR, Silva AC, Verreschi IT, Sawaya AL. Influência das condições socioeconômicas nas alterações nutricionais e na taxa de metabolismo de repouso em crianças escolares moradoras em favelas no município de São Paulo. Rev Assoc Med Bras. 2000;46:7-14.

21. Silva GA, Balaban G, Motta ME. Prevalência de sobrepeso e obesidade em crianças e adolescentes de diferentes condições sócioeconômicas. Rev Bras Saude Matern Infant. 2005;5:53-9.

22. Godfrey KM, Barker DJ. Fetal nutrition and adult disease. Am J Clin Nutr. 2000;71:1344S-52S.

23. Ong KK. Size at birth, posnatal growth and risk of obesity. Horm Res. 2006;65 Suppl 3:65-9.

24. Monteiro CA. A dimensão da pobreza, da desnutrição e da fome no Brasil. Estud Av. 2003;17:195-207.

25. Sichieri R, Silva CV, Moura AS. Combined effect of short stature and socioeconomic status on body mass índex and weight gain during reproductive age in Brazilian women. Braz J Med Biol Res. 2003;36:1319-25.

26. Ravelli GP, Stein ZA, Susser MW. Obesity in young men after famine exposure in utero and early infancy. N Engl J Med. 1976;295:349-53.

27. Vitolo MR, Gama CM, Bortolini GA, Campagnolo PD, Drachler Mde L. Some risk factors associated with overweight, stunting and wasting among children under 5 years old. J Pediatr (Rio J). 2008; $84: 251-7$.

28. Coutinho JG, Gentil PC, Toral N. A desnutrição e obesidade no Brasil: o enfrentamento com base na agenda única da nutrição. Cad Saude Publica. 2008;24 Suppl 2:332-40.

29. Engstrom EM, Anjos LA. Déficit estatural nas crianças brasileiras: relação com condições sócio-ambientais e estado nutricional materno. Cad Saude Publica. 1999;15:559-67.

30. Martins IS, Marinho SP, de Oliveira DC, de Araújo EA. Pobreza, desnutrição e obesidade: inter-relação de estados nutricionais de indivíduos de uma mesma família. Cien Saude Colet. 2007;12:1553-66.

Correspondence:

Telma Maria de Menezes Toledo Florêncio

Rua Higia Vasconcelos 401/701 - Ponta Verde

CEP 57035-140 - Maceió, AL - Brazil

Tel.: +55 (82) 3326.5907, +55 (82) 9981.2218

E-mail: telmatf_al@hotmail.com 